\title{
FOREIGNIZATION AND DOMESTICATION IN TRANSLATING CULTURE-SPECIFIC ITEMS IN THE ENGLISH TRANSLATION OF AHMAD TOHARI'S LINTANG KEMUKUS
}

\author{
Leni Tiwiyanti \\ Universitas Indraprasta PGRI \\ Po el: lenitiwiyanti@gmail.com \\ HP: 085714142808
}

\begin{abstract}
A good translation has become a bridge among different cultures from different countries. The terms foreignization and domestication have been proposed to deal with culture-specific items found in the source text. Both terms have become the focus of arguement in the recent years. The purpose of this research is to identify translation procedures in translating culture specific items that are termed as foreignizing and domesticating and to identify how foreignization and domestication are applied in translating culture specific items. The method used is qualitative descriptive method. The data analysis shows that in translating the source text, translator prefers to apply domestication. There are $74.64 \%$ data which are translated using domestication and only $23.36 \%$ data are translated using foreignization. Domestication is prefered as it will allow target text readers to understand the text easily. Moreover, the minority position of the source text cultureof does not allow foreignization to be applied in a greater extent. Foreignization is only applied to translate central culture-specific items in order to bring the local nuanse of the source text culture.
\end{abstract}

Keywords: translation, forignization, domestication, culture-specific items

\begin{abstract}
ABSTRTAK
Penerjemahan yang baik berperan sebagai jembatan antarbudaya dari negara yang berbeda. Istilah foreignizationdan domestikasi telah diajukan guna mengatasi istilah budaya yang ditemukan dalam teks sumber. Kedua istilah tersebut telah menjadi perdebatan beberapa tahun terakhir ini. Penelitian ini bertujuan untuk mengenali prosedur penerjemahan dalam menerjemahkan istilah budaya berdasarkan strategi foreignization dan domestikasi dan untuk melihat bagaimana foreignization dan domestikasi digunakan dalam menerjemahkan istilah budaya. Metode yang digunakan adalah metode deskriptif kualitatif. Analisis data menunjukkan bahwa dalam menerjemahkan teks sumber, penerjemah lebih memilih menggunakan foreignization dan strategi domestikasi. Terdapat $74.64 \%$ data yang menggunakan domestikasi dan hanya $23.36 \%$ data yang menggunakan foreignization. Domestikasi lebih dipilih guna membantu pembaca teks sasaran untuk memahami teks dengan mudah. Selain itu, budaya teks sumber yang masih minoritas belum memungkinkan menerapkan strategiforeignization. Foreignizationhanya digunakan untuk menerjemahkan istilah budaya yang penting dalam cerita yang menampilkan nuansa lokal dari budaya teks sumber.
\end{abstract}

Kata kunci: penerjemahan, Foreignization, domestikasi 


\section{INTRODUCTION \\ Research Background}

Different culture has different concept about the world. These differences are manifested through the language used as well. The language is not merely a mark or sign but it is also one of the main components of cultural structures to carry massive information about the culture. So, the exchange of two languages occured in translation is automatically related to the exchange of two different cultures. It is translation which has been a bridge among different cultures.

Translation has made it possible to exchange culture by translating great literary works of a certain language into two or more different languages. However, each community has its own unique culture which eventually brings problems in translation. A good translation which plays as a good communication has become a bridge among different countries. To deal with the differences, some translators recently come up with the terms foreignization and domestication. Both terms have become the focal points which the people argued in the recent years. The arguement basically lies on the difficulties for the translation to maintain the style, the nuance and the flavor of the original work as much as possible and for the readers to understand and accept the translation as easily as possible.

Some people argue that foreignization may be better, but other people thought that domestication is more appropriate. In practice, translators find the fact that excessively applying domestication or foreignization is not the best option.Some pay great attention to the readability of the target text. This is commonly welcomed by target text readers as the practice will make simple translation; therefore, the domestication had been always in the dominant position. Yet, globalization, information networking and business intercourse require cultural exchange between different cultures. The fact requests translators to introduce and disseminate culture-specific items of foreign culture to be retained at a much greater extent. This lead translators to prefer foreignization to domestication. However, prefering foreignization does not mean neglecting or repelling domestication. The relation between them is supplementary and may not be substituted by each other. Translator should consider when and how is the best place and time to apply them.

\section{Research Problems}

The followings are the research problems:

1. What translation procedures in translating culture specific items are termed as foreignizing and domesticating?

2. How foreignization and domestication are appplied in translating culture specific items?

\section{Research Objectives}

1. To identify translation procedures in translating culture specific items that are termed as foreignizing and domesticating. 
2. To identify how foreignization and domestication are applied in translating culture specific items.

\section{THEORETICAL BACKGROUND}

\section{Culture Specific items}

Based on the definition proposed by Larson, culture is "a complex of beliefs, attitudes, values, and rules which a group of people share" (Larson 1984: 431). Newmark also defines culture but he emphasises the relation between culture and language. He states that:

"I am referring to culture only in anthropological sense i.e. the way of life and environment peculiar to the native inhabitants of a particular geographical area, restricted by its language boundaries, as manifested through a single language (Newmark, 2010: 173).

In short, we can see that culture is about a complex of beliefs, attitudes, values, and rules which a group of people share which are manifested through a particular language. Different culture will have different language.

Culture-specific items are words and phrases which are determined by cultural diversity. Cultural diversity is highly obvious between one culture to another. Lewis states that, "we readily accept that cultural diversity is vast and formidable" (Lewis, 2006: 4). Baker defines Culture-specific items as the following:

The source-language word may express a concept which is totally unknown in the target culture. The concept in question may be abstract or concrete; it may relate to a religious belief, a social custom, or even a type of food. Such concepts are often referred to as 'culture specific' (Baker 1992: 21).

Based on Baker's definition above, culture-specific items are any concepts that exist in a language and refer to any cultural entity which is commonly unfamiliar to the members of the other culture.

Further on, Baker categorizes culture-specific items into two, "The concept in question [CSI] may be abstract or concrete" (Baker, 1992: 21). Unfortunately, the categorisation is not further defined in the book.

Newmark (2010: 173--177) distinguishes six categories of culture-specific items into ecology, public life, social life, personal life, customs and pursuits, and private passions. Ecology encompasses refers to geological and geographical environment, e.g., Naples, Lyon, fjord. Public life refers to politics, law and government, e.g., the House of Commons, Prime Minister. Social life includes economy, occupations, social welfare, health and education, e.g., the patients are admitted or discharged from the hospital and not accepted or rejected. Personal life encompasses food, clothing and housing, e.g., pasta, paella, espresso, mocha. Customs and pursuits refer to various body language signs that are specific to particular culture, e.g., slow hand clapping means applause, and various means 
of entertainment, e.g., cricket and football with their national idioms such as sticky wicket. Private passions include religion, music, poetry and their different social organisations, e.g., Methodism, Shakespeare, the Arts Councils.

\section{Translating culture-specific items}

Culture-specific items are one of the most frequently encounter problems in translation. Translation studies has never stopped talking about the problem that culturespecific items bring. Translators have to consider many things to deal with them. There are many theorists who discuss about the matter. Translation activity requires making a great number of decisions and consequently carries many risks of making mistakes (Meyer, 2006: 230--232). The issue on translation of culture-specific items is always debatable. Mona Baker places culture-specific items in the section of the most common problems (Baker 1992: 21). Further on, still on the same arguement, Newmark supports the notion that "culture as the greatest obstacle to translation, at least to the achievement of an accurate and decent translation" (Newmark, 2010: 172--173). Translators are always in search of the better or even the best way to translate culture-specific items accurately and decently without making any mistakes.

Translators play as a 'bridge' who help the target text readers to understand the culture-specific items of the unfamiliar source text readers. As stated by Davies who proposes that "The translator is portrayed as a mediator whose task is to make these various cultural manifestations accessible to the reader of the translation" (Davies 2003: 68).

Differences in cultural background causes many problems since the source text may include concepts which are unfamilar to the target text readers. Shäffner and Wieserman explains that translation problems arise because "the target readers cannot (always) be supposed to be fully familiar with the source culture" (Shäffner and Wieserman 2001: 33). It is the task of a translator to make the source text culture accessible by the target text readers.

\section{Foreignization and Domestication}

Lawrence Venuti is known to be the one who introduced the terms foreignization and domestication strategies into translation studies in 1995. Venuti (1995: 19-20) discusses invisibility hand in hand with two types of translating strategy: doemstication and foreignization. However, the terms actually have long been known before Venuti introduced them. Domestication has been known at least since ancient Rome, and foreignization at least was introduced at least since the Classical and Romantic periods of German culture (Venuti:1998:240). The terms of foreignization and domestication have been argued for years. The fact that the style and and sense of the original work are difficult to maintain as far as possible and to be understood and acceptable by the readers in the translation draws translators to consider these two strategies in their translation. 
Some people think foreignization may be a better choice compared to dmestication, but some other people think that domestication is more suitable to convey meaning. Domestication is more dominant in UK-US translation as translators concern more on the readers' response. From this point, translators should know the target text language's custom, cultural information and cultural difference so that translators will have the ability to convey the right message.

\section{Foreignization}

In 1970's, at the forum of contemporary international translation, Venuti was recognized as the representative of foreignization. He proposed the concept which gave the prominence to "foreignness" of the source text, either in style or any other aspects contained in the source text language. In this type of translation, readers are urged to accept foreign culture concepts. Translators do not compromise with the readers.

Venuti was not the first to introduce foreignization. The term foreignization strategy can be traced back to the German culture of the Classical and Romantic periods as it was proposed by Schleiermacher. Schleiermacher introduces foreignization because of the intended readership and because it can benefit the target text language. Schleiermacher prefers foreignization as he states that 'the translator leaves the writer alone, as much as possible and moves the reader towards the writer' (in Munday, 2008:147)

When foreignization is used, culture specific items which contain cultural information of the source text language will be preserved, and the readers will feel the atmosphere and sense of the source text language culture in a greater degree. However, it should be understood that foreignization is not simple translation from word to word, forignization only retains particular source text language which convey semantically structure concept and they are mostly concerns about culture specific items.

In case of translator visibility, Venuti strongly prefers the foreignizing strategy as it makes the translators 'visible' to the readers, and this will lead to the recognizion of the translators. Upon reading, readers will find some foreign concepts which are retained in the target text. This eventually makes the target text readers aware of the foreign source text elements which are preseved. Target text readers will be aware of the exictence of the source text in another language, and, eventually, realize the exictence of the translator.

Venuti recommends foreignization as he argues that it is unfair to use domestication. Venuti (1995:20) states that domestication involves 'an ethnocentric reduction of the foreign text to the target-language cultural values'. In domestication, foreign cultural values are excluded or adapted to fit into the domestic value system of the target text language.

Foreignization translation is also slowly accepted by the readers. The foreignization in translation is seen to play a more vital role as it deepens communication between various countries. Target text readers will have the chance to know the culture of the source text language and the target text language will be able to enrich itself. As we all know, language 
is not a sealed system; consequently, a good foreignization in translation is surely advantageous to enrich the target text language. Foreignization will give the opportunity for the target text language to absorb some new language elements of the source text language. Once certain vocabularies or culture specific items are accepted by the society, they will gradually be regarded as new members of the target text languages.

\section{Domestication}

Domestication is a translation strategy of using a transparent, fluent, 'invisible' style in order to minimize foreignness of the target text (Munday, 2008: 144) Domestication has long been implemented since Ancient Rome. This strategy is usually not only concern about cultural conflict, but it also concerns with political. Certain culture may use this strategy because of its imperialistic tendencies as in the translation done by the contemporary Anglo-American culture. Domestication may be seen benefit the target text readers; however, it presents a problem regarding transfer of meaning. According to Venuti (1995: 469), domestication involves 'an ethnocentric reduction of the foreign text to AngloAmerican cultural values.' In domestication, foreign culture-specific items are excluded, they are replaced by domestic culture-specific items to fit into the domestic value system. Another consequence of domestication is that it makes the translator invisible because the target text readers will read the translation like an original text.

Domestication emphasizes more on easy understanding. Target text readers will not find difficulties in dealing with the cultural difference between the original text and the translation. The main characteristic of domestication is on its smooth and pure target text language to translate the source text language. Upon doing this, the smooth translation will cover the difference possed by the two different cultures. Target text readers will easily accept the translation without any difficulties. In domestication, the source text's culture and language style are replaced by the target text cultures and languages. Idioms, phrases, figurative languages, cultural specific items will be understood easily.

\section{METHODOLOGY}

\section{Research method}

This research is a qualitative reseach and library research. It is qualitative in which the researcher observes the use of foreignization and domestication in translating culturespecific items found in the novel and its translation. The researcher also uses theories available to analyze the foreignization and domestication strategies, culture-specific items and the translation procedures applied by the translators.

\section{Data Collection}

For the purpose of this research, the researcher used the novel entitled 'Lintang Kemukus' by Ahmad Tohari and its translation version in English entitled 'Shooting Star at 
Dawn" which is translated by Rene T. A. Lysloff as the source of the data. The data are culture-specific items found in the novels.

\section{Data Analysis}

The data will be analyzed as follows:

1. The researcher analyze the source text thoroughly to recognize all culture-specific items used in the source text.

2. At the same time, the researcher look for the equivalence of the source text culturespecific items given by the translator in the target text.

3. After the data are collected, the reasearcher checks the data in dictionary to check the meaning to some dictionaries.

4. Next, the researcher classifies the data based on the translation procedures used by the translator in the target text.

5. Then, the researcher classifies the translation procedure into foreignization or domestication strategy

6. Finally, the writer draws conclusion based on the data analysis.

\section{RESEARCH ANALYSIS}

\section{Foreignizing and Domesticating Procedures}

In this research, the researcher find 35 culture-specific items translated with foreignization strategy and 104 culture-specific items translated with domestication strategy.

\section{a. Foreignizing Procedures}

In the translation version of the novel, the researcher finds there are 2 procedures which use foreignizing precedures; namely loan word without modification and loan word with modification.

1) Loan word without modification

In this procedure, we can see how translator chooses to translate the source text into the target text without any modification. The words and phrases of the source text are preserved in the translation. This procedure will give the reader the chance to know the real setting of the story so that they can feel the same impression felt by the source text readers.

As we all know, Ahmad Tohari is a well-known literary writer in Indonesia. His novels are mostly on Indonesian indiginous people. The setting described in his novels is specially designed to depict Indonesian people. There are many ecological concepts that the writer brings into the novel. This fact need special consideration by the translator. 
In the tables below, we can see the data showing how the translator applies foreignization by using loan words taken from the source text.

\begin{tabular}{|l|l|}
\hline \multicolumn{1}{|c|}{ Source Text } & \multicolumn{1}{|c|}{ Target Text } \\
\hline $\begin{array}{l}\text { Dan ronggeng itu merasa } \\
\text { heran mengapa ada seorang } \\
\text { lelaki dari jenis lainnya. (p.4) }\end{array}$ & $\begin{array}{l}\text { The ronggeng felt surprised } \\
\text { that there existed one amn } \\
\text { (p.120) }\end{array}$ \\
\hline
\end{tabular}

In the data above, the source text 'ronggeng' is translated into 'ronggeng' which means the translator simply uses the source text culturespecific item in the target text. the story itself tells about Srintil, a ronggeng, a tranditional dancer in Dukuh Paruk, so the translator should emphasis on the culture-specific word. The translator does not translate into 'a tranditional dancer' or any other equivalence as the concept of 'ronggeng' is highly different from the concept ' traditional dancer'. Therefore, the procedure used compromise with foreignization strategy as it helps the target text readers to know the culture-specific item of the source text.

\begin{tabular}{|c|c|}
\hline Source Text & Target Text \\
\hline $\begin{array}{l}\text { Pasangan penjaja musik } \\
\text { kecapi itu tahu betul saat } \\
\text { yang tepat di mana musiknya } \\
\text { menjadi kebutuhan para } \\
\text { pelanggan. (p.20) }\end{array}$ & $\begin{array}{l}\ldots \text {, a couple who gave } \\
\text { kecapi performances for a } \\
\text { living, .... (p.136) }\end{array}$ \\
\hline
\end{tabular}

The phrase 'musik kecapi' is translated into 'kecapi performance'. In this case, the translator retains the source text culture-specific word 'kecapi' in order to introduce the concept 'kecapi' to the target text readers. Kecapiis a tranditional music from Indonesia and the target text readers are not familiar with the culture-specific word.

\begin{tabular}{|l|l|}
\hline \multicolumn{1}{|c|}{ Source Text } & \multicolumn{1}{c|}{ Target Text } \\
\hline $\begin{array}{l}\text { Kadang dia berkicau seperti } \\
\text { kutilang, .... (p.102) }\end{array}$ & $\begin{array}{l}\text { Sometimes, they sang like } \\
\text { the kutilang, .... (p.223) }\end{array}$ \\
\hline
\end{tabular}

In the data above, the culture sepcific words 'kutilang'is merely translated using the loan word with an addition 'the' before the word. This is done as it will facilitate the target text readers to know the source text culture. Translator does not have to add any other word or phrases as the context has already given the notion that those are names of birds.

\begin{tabular}{|c|c|}
\hline Source Text & Target Text \\
\hline $\begin{array}{l}\text { Nasi dengan lauk ten } \\
\text { goreng, sambal, dan lalal }\end{array}$ & $\begin{array}{l}\text { She had prepared } \\
\text { with several dish }\end{array}$ \\
\hline
\end{tabular}




\begin{tabular}{|l|l|l|}
\hline $\begin{array}{l}\text { sudah ditata di meja makan } \\
\text { (p.121) }\end{array}$ & $\begin{array}{l}\text { side: fried tempeh, } \\
(\mathrm{p} .242)\end{array}$ \\
\hline
\end{tabular}

The source text culture -specific word 'tempe' is retained but with naturalization by adding ' $h$ ' sound to adapt with the target text readers. However, the word 'tempeh' is still foreign and this allows target text readers to know the new concept. The context has already mentions that the word 'tempe' is a kind of food .

2) Loan word modification

The other procedure applied by the translator is using loan word with modification. In this procedure, translator uses the loan word and adds some explanantion to the source text culture specific words or phrases to help target text readers comprehend the message.

\begin{tabular}{|l|l|}
\hline \multicolumn{1}{|c|}{ Source Text } & \multicolumn{1}{c|}{ Target Text } \\
\hline $\begin{array}{l}\text { Bunyinya akan mampu } \\
\text { menerjemahkan suara puluhan } \\
\text { blentung, .... (p.22) }\end{array}$ & $\begin{array}{l}\text { It's tones would have the } \\
\text { power to interpret the sound } \\
\text { of a host of blentung } \\
\text { insects, ... (p.137) }\end{array}$ \\
\hline
\end{tabular}

The word 'bletung' refers to a kind of frog which has loud voice and small body. The translator chooses to translate it into 'blentung insect' which refers to the general concept of the animal. He keeps the word 'blentung' but then adds 'insect' as the classifier as further information.

We can see that there is misinformation that the translator gives. The equivalence is actually not acceptable because target text readers get the notion that the animal belongs to insects. Frog is not classified as insects. However, the word 'blentung' is not vital in the story so it will not disturb the information flow during the reading activity.

\begin{tabular}{|c|c|}
\hline Source Text & Target Text \\
\hline $\begin{array}{l}\text { Melihat keadaannya dua di } \\
\text { antara mereka tentulah } \\
\text { tengkulak terasi, .... (p.62) }\end{array}$ & $\begin{array}{l}\text { Two of them were traders of } \\
\text { terasi, a pungent spice } \\
\text { made from shrimp, crabs } \\
\text { and other seafood (p. } 181)\end{array}$ \\
\hline
\end{tabular}

In the data, the word 'terasi' is translated into 'terasi, a pungentspice made from shrimp, crabs and other seafood'. The translator uses descriptive equivalence to translate the source text. The equivalence helps the target text readers to get the clear concept of the culture-specific word yet it can still give the local nuanse of the source text. 


\section{b. Domestication Procedures}

In these procedures, translator focuses on domestication strategy. In total, there are 104 data found using domestication strategy. In the translation, the source text culture-specific items are not used. There are four translation procedures used; descriptive equivalence, cultural substitution, general words, and deletion.

All of the four procedures are used to help target text readers understanding the target text easily. No alienating words or phrases that disturb the information flow. All the words and phrases used are familiar to them.

\section{1) Descriptive equivalence}

In descriptive equivalence procedure, the source text culture-specific items are translated with description. The followings are the analysis of descriptive equivalence found in the novel.

\begin{tabular}{|c|c|}
\hline Text & TaI \\
\hline $\begin{array}{l}\text { Termangu-mangu di atas } \\
\text { lincak, Srintil merasakan } \\
\text { kesejukan.... (p. 18) }\end{array}$ & $\begin{array}{l}\text { Srintil sat down on a low } \\
\text { bamboo benchbeside the } \\
\text { shopkeeper. (p.133) }\end{array}$ \\
\hline
\end{tabular}

The specific-culture word 'lincak' is translated into 'a low bamboo bench'. The descriptive equivalence procedure can transfer the message well as it gives the form and function of the source text culture-specific word.

\begin{tabular}{|c|c|}
\hline e Text & Target Text \\
\hline $\begin{array}{l}\text { Wirsiter dengan blangkon, } \\
\text { baju lurik serta kain batik } \\
\text { yang diwiru. (p.21) }\end{array}$ & $\begin{array}{l}\text { Wisiter was wearing ... and a } \\
\text { neatly folded wrap-around } \\
\text { skirt (p.136) }\end{array}$ \\
\hline
\end{tabular}

The culture specific word 'diwiru' which belongs tp custom and pursuit is translated into 'folded wrap-around'. This procedure by giving descriptive equivalence can convey the message well as it give s information on the actual form.

\begin{tabular}{|l|l|}
\hline \multicolumn{1}{|c|}{ Source Text } & \multicolumn{1}{|c|}{ Target Text } \\
\hline $\begin{array}{l}\text { Terbayang kembali olehnya } \\
\text { suatu ketika di malam hari } \\
\text { menjelang acara bukak- } \\
\text { klambu ...(p.59) }\end{array}$ & $\begin{array}{l}\text { Her memories returned to the } \\
\text { approaching hour of her } \\
\text { ritual ditual of deflowering ... } \\
\text { (p.178) }\end{array}$ \\
\hline
\end{tabular}


The phrase 'bukak-klambu' belong to custom and pursuit in culturespecific items classification. This phrase is semantically dense in meaning as it is a ritual that roggeng has in which she will give her virginity to any man who can give the highest price for her. Unfortunately, the equivalence 'ritual of deflowering' cannot represent the concept well as there are many information lost in the translation. This is actually crucial in the story as the story itself tells about the life of a ronggeng.

\begin{tabular}{|l|l|}
\hline \multicolumn{3}{|c|}{ Source Text } & \multicolumn{1}{c|}{ Target Text } \\
\hline $\begin{array}{l}\text {.. di halamannya tumbuh } \\
\text { pohon-pohon sawo yang } \\
\text { rindang (p.105) }\end{array}$ & $\begin{array}{l}\text { tall learge yard bounded by } \\
\text { trees (p.226) }\end{array}$ \\
\hline
\end{tabular}

The phrase 'pohon-pohon sawo' is an unfamiliar concept for the target text readers as they don't have the exact tree in theor environment. Sawo tree is one of the tropical tree commonly found in Indonesia, and it is big and has lots of leaves.Therefore, the translator uses 'leavy trees' as the equivalence can describe the tree well.

\begin{tabular}{|l|lr|}
\hline \multicolumn{1}{|c|}{ Source Text } & \multicolumn{3}{|c|}{ Target Text } \\
\hline $\begin{array}{l}\text { Nasi dari padi gogo dengan } \\
\text { lodeh rebung dan gulai ayam } \\
\text { (p.107) }\end{array}$ & $\begin{array}{l}\text { Dishes made } \\
\text { vegetables, coconut }\end{array}$ & milk \\
& (p.228) & \\
\hline
\end{tabular}

As we can see in the data above, translator gives explanation by using words and phrases that are familiar and more neutral to the target text readers. The word 'lodeh' is not familiar to the target text readers, so the translator uses descriptive equivalence procedure to translate. The equivalence ' dishes' represent the general concept of the culture-specific word and the rest of the explanantion, made from vegetables, coconut milk' will give information on the kind of food of the source text culture-specific word.

\section{2) Cultural substitute}

Another way to domesticate the target text is by using cultural substitute. In this procedure, translator finds an object that the target text readers familiar with that they have in their culture and can best replace the source text culture specific items as they have similarities.

\begin{tabular}{|c|c|}
\hline Source Text & Target Te \\
\hline $\begin{array}{lcr}\text { Burung } & \text { sikatan } & \text { mencecet- } \\
\text { cecet } & \text { dari } & \text { tempat } \\
\text { persembunyiannya. } & (\text { p. } 1)\end{array}$ & $\begin{array}{l}\text { The wagtailchirped from its } \\
\text { hiding place.... (p.117) }\end{array}$ \\
\hline
\end{tabular}


In this data, the translator uses 'the wagtail' as the equivalence for the culture-specific phrase 'burung sikatan'. The equivalence 'Wagtail' is choosen for two reasons. First, it is a familiar kind of bird for the target text readers. Second, it has similarities with 'burung singkatan'.

\begin{tabular}{|l|l|}
\hline \multicolumn{1}{|c|}{ Source Text } & \multicolumn{1}{c|}{ Target Text } \\
\hline $\begin{array}{l}\text { Sulam, Lurah Pecikalan atau } \\
\text {....(p.4) }\end{array}$ & $\begin{array}{l}\text { Sulam, the chief if Pecikalan, } \\
\text {... (p.120) }\end{array}$ \\
\hline
\end{tabular}

The word 'lurah' is translated into 'chief'. The concept 'chief' belongs to public life culture-specific items. The target text culture uses the terms to refers to a leader of a certain territory, just like the word 'lurah'. Although the concept of territory between the two cultures is different, the word can still represent alike meaning for the source text culture-specific word.

\begin{tabular}{|l|l|}
\hline \multicolumn{1}{|c|}{ Source Text } & \multicolumn{1}{c|}{ Target Text } \\
\hline $\begin{array}{l}\text {.. dan konde berhiaskan } \\
\text { bunga melati. (p.21) }\end{array}$ & $\begin{array}{l}\text {. and a chignon adorned } \\
\text { with jasmine flowers on top. } \\
\text { (p.136) }\end{array}$ \\
\hline
\end{tabular}

The word 'konde' in the data is translated into 'a chignon'. The word 'chignon' is not the exact equivalence for the source text culture-specific word, but it has similarities that make it best replace the word 'konde' as it will help the target text readers to understand the concept.

\section{3) General words}

The last procedure to translate the culture-specific items is general words. There are 25 data using the procedure. In this procedure, the translator simply gives the general words of the source text culture-specific items. This procedure will also help the target text readers to understand the target text easily as the equivalence chosen are familiar to them.

The followings are the data showing translation by using general words:

\begin{tabular}{|c|c|}
\hline Source Text & Target Text \\
\hline $\begin{array}{l}\text { Dan Srintil terkejut ketika } \\
\text { terdengar suara tokek dari } \\
\text { bubungan cungkup makam Ki } \\
\text { Secamenggala. (p.9) }\end{array}$ & $\begin{array}{l}\text { Srintil was startled by the sound } \\
\text { of a gecko which was hidden in } \\
\text { the eaves of Ki } \\
\text { Secamenggala's memorial } \\
\text { (p.125) }\end{array}$ \\
\hline
\end{tabular}


In the data above, the culture-specific phrase is translated into 'the eaves'. Translator uses general word 'the eaves' which refers to the part of a roof that meets or overhangs the walls of a building. The concept source text culture-specific items is not best conveyed as 'bubungan cungkup' has particular form and function than just an eaves. However, the translation is acceptable as the culture-specific word is not important in the story.

\begin{tabular}{|lll|l|}
\hline Kodok longan itu akan & The frogwould spend the day
\end{tabular} bersembunyi sepanjang hari di hidden in cool dark space kolong balai-balai, .... (p.49) beneath the raised sleeping platform, .... (p.167)

The culture-specific word 'kodok longan' is translated by its general word 'frog'. This procedure helps the target text readers to grasp the concept easily without being disturbed by any unfamiliar word.

\begin{tabular}{|c|c|}
\hline $\begin{array}{l}\text {.. tangannya yang cekatan d } \\
\text { senggakannya yang kocak d } \\
\text { konyol. (p. } 114 \text { ) }\end{array}$ & $\begin{array}{l}\text {... his adept hands, and his } \\
\text { foolish and hilarious calls } \\
\text { (p.232) }\end{array}$ \\
\hline
\end{tabular}

The culture-specific word 'senggakannya' is translated into its general concept 'calls'. The word 'senggakan' is actually not exactly the same with the word 'calls' as it is a calling made by someone in a dance performance. However, the word still can best replace the concept as it is similar with its general concept 'calls'

\section{4) Deletion}

This procedure simply deletes the culture-specific items of the source text. This procedure is used merely to allow target text readers to understand the text easily. The data below show the culture-specific items of the source text which are deleted. They are basically not crucial in the text; therefore, it is possible to delete them. Translator emphasizes on the target text readership in this case.

\begin{tabular}{|c|c|}
\hline Source Text & Target Text \\
\hline $\begin{array}{l}\text { Niyatingsun matak aji } \\
\text { pamurung Hadi aing } \\
\text { tampean aing cikaruntung } \\
\text { nantung Ditarbuan boeh } \\
\text { sana, manci rasa marang } \\
\text { Srintil marang Rasus Kene } \\
\text { wurung kana wurung, pes } \\
\text { mimpes dening Eyang }\end{array}$ & 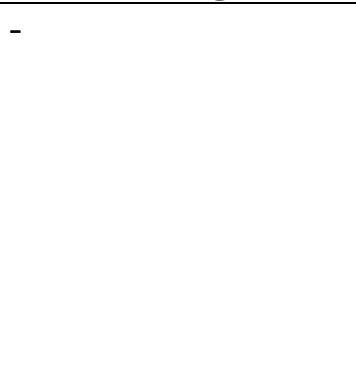 \\
\hline
\end{tabular}




\begin{tabular}{|l|}
\hline Secamenggala Pentil alum \\
cucuk layu, angen sira \\
bungker Si Srintil Si Rasus \\
Ker bungker, ker bungker \\
kersaner Eyang \\
Secamanggala Ker bungker, \\
ker bungker kersane Sing \\
Murbeng Dumadi $(p .22)$ \\
\hline
\end{tabular}

The source text culture-specific song above is not translated by the translator as it posses great difficulty to be translated and it does not play crucial part in the story. This deletion procedure will later help the target text readers to understand the target text easily without any alienating culture-specific items.

\section{Application of Foreignization and Domestication in translating Culture- specific items}

In translating the novel, the translator applies both foreignization and domestication strategies. Both strategis are used but in different cases. Most of the culture-specific items are translated using domestication startegy as the translation version, an English version, is expected to be accepted and be easily read by the target text readers.

The following is the table showing the distribution of strategy used in translating the novel.

Tabel 1Distribution of foreignization and domestication strategy

\begin{tabular}{|l|c|c|}
\hline \multicolumn{1}{|c|}{ Strategy } & Application & Percentage \\
\hline Foreignization & 35 & $25.36 \%$ \\
\hline Domestication & 103 & $74.64 \%$ \\
\hline
\end{tabular}

Foreignization is used to bring the nuanse of the source text culture. The novel which was first published in 1981 and written by Ahamad Tohari is known as a novel which sets in Dukuh Paruk and present local color of Indonesian culture. The translator chooses to use the startegy for some of the culture-specific items to allow the target text readers to know some of the culture-specific items of the particular culture presented in the novel. Some culture-specific items require foreignization as the items are the focus of the story, but others are just to bring the local nuanse of the story setting.

Domestication is applied to translate culture-specific items which are not crucial in the text. This is more prefered by the translator to the foreignization as it allow the target text readers to understand the story easily. 


\section{CONCLUSION}

Based on the analysis on the application of foreignization and domestication in translating culture-specific items, we can assess the degree of domestication or foreignization in a translation. From the analysis, domestication prevails as it is applied to $74.64 \%$ of the data. Foreignization is only applied to $23.36 \%$ of the data. The procedures which compromize with foreigization startegy are loan word without modification and loan word with modification. The modifictaion added are classifiers or further explanantion of the loan word. Domestication stategy is shown by 4 types of procedures; namely descritptive equivalence, cultural substitutes, general words and deletion. In deletion, the translator simply does not give the equivalence.

Translating culture-specific items need special considerations. To give an acceptable equivalence in the traslation, translators need to know the culture-specific items well. It is expected that translator can play as a bridge that allow target text readers to know new unfamiliar culture-specific items after readeing the novel.

The choices of using foreignization and domestication are based on many reasons. Translation strategy used reflects the social and cultural trend in the society. From the data we can say that English speaking readers are still not welcome to many culture-specific items from other culture. That is why, domestication prevails. Domestication is prefered as it help target text readers to understand the text easily. Usually the culture-specific items which are replaced are not the focus of the story. However, there is a tendency for the target text reader, the English speakers, to welcome unfamiliar culture-specific items as globalization leads people to interact one another. In the novel, foreignization is applied to culture-specific words which are crucial and be the central attention. Foreignization applied in the target text will make it possibl for target text readers to fell the tranditional or local nuanse of the source text culture. 


\section{REFERENCES}

Baker, Mona. 1992. In Other Words: A Course Book on Translation. London: Routledge.

Larson, Mildred L. 1984. Meaning-Based Translation: A Guide to Cross -Language Equivalence.Lanham and New York: University Press of America.

Lewis, Richard D. 2006. When Cultures Collide: Leading across Cultures. Boston and London: NicolasBrealey International.

Meyer, Ingrid.2006. Lexicography, Terminology, and Translation. Ontario: University of Ottawa Press.

Munday, Jeremy.2008. Introducing Translation Studies: Theories and Applications. 2nd Edition.London-New York: Routledge

Newmark, Peter. 2010. Translation andCulture. In Meaning in Translation. Ed. B. Lewandowska-Tomaszczyk. Frankfurt: Peter Long GmbH

Schäffner, Christina and Uwe Wiesemann. 2001. Annotated Texts for Translation: EnglishGerman:Functionalist Approaches Illustrated. Frankfurt: Multilingual Matters.

Venuti, Lawrence. 1995. TheTranslator's Invisibility: A History of Translation. London and New York:Routledge.

. 1998. The Scandals of Translation: Towards an Ethics of Difference. London and New York: Routledge. . 2000. Translation, Community, Utopia. Venuti (ed).The Translation Studies Reader,London: Routledge. 